8. Sarana, S. V. (2014). Protsesualno-protsedurnyi podatkovyi rezhym: sutnist ta oznaky [Procedural Procedural Tax Regime: Essence and Signs]. Finance law, no 4(30), pp. 28-31.

9. Kolesnik, L. I. (2017). Protsesualni rezhymy u podatkovomu protsesi [Procedural Regimes in the Tax Process] (PhD Thesis), Kiev: Open International University for Human Development «Ukraine», $188 \mathrm{p}$.

10. Minaieva, O. M. (2014). Do pytannia shchodo dzherel ta struktury podatkovoho protsesu [To the question of the sources and structure of the tax process]. Customs business, no 2(92), pp. 255-259.

\title{
INTERNATIONAL CONVENTIONS AND NATIONAL LEGISLATION: USING PRIORITY
}

\section{Olha Kuchma ${ }^{1}$ \\ Liudmyla Sinova ${ }^{2}$}

\section{DOI: https://doi.org/10.30525/978-9934-588-11-2_61}

Ukraine, like many other countries, is taking part in the international arena, concludes contracts, ratifies treaties. According to the paragraph 9 of the Constitution of Ukraine, current internationals treaties, which the Verkhovna Rada has recognized, are the part of national legislation of Ukraine [1].

The Law of Ukraine «About the ratification of International Labour Organization Convention № 132 (revised) of 1970 Holidays with Pay» provides the following: International Labour Organization Convention № 132 (revised) of 1970 Holidays with Pay, adopted by 54th session of General Conference of International Labour Organization on the 24th of June 1970 must be ratified with the following appeal: «Ukraine, according to the paragraph 15 of the Convention claims, that will take all the obligations towards people, who participate in employment in all spheres of economy, including agriculture» [2].

In Republic of Latvia all international agreements, which regulate legal issues, must be approved by the Sejm. While concluding the agreement Latvia can delegate part of the competence from state institutions to international institutions in order to strengthen democracy. Sejm can approve international treaties, which are the ground for delegation of part of the competence from state institutions to international institutions at the conference, where at least two thirds of deputies are present [3].

Latvia is a member country of International Labour Organization (ILO). Latvia has renewed its membership in 1991. Currently there are 42 ratified ILO Conventions in force. ILO has been created as a first specialized agency of United Nations (UN) in 1919 and nowadays it integrates 185 countries. The main target of organization facilitation the social justice and recognition of international labour laws [4].

According to the paragraph 7 of the ILO Convention № 132 «every person taking the holiday envisaged in this Convention shall receive in respect of the full period of

\footnotetext{
${ }^{1}$ Taras Shevchenko National University of Kyiv, Ukraine

2 Taras Shevchenko National University of Kyiv, Ukraine
} 
that holiday at least his normal or average remuneration (including the cash equivalent of any part of that remuneration which is paid in kind and which is not a permanent benefit continuing whether or not the person concerned is on holiday), calculated in a manner to be determined by the competent authority or through the appropriate machinery in each country. The amounts due in pursuance of paragraph 1 of this Article shall be paid to the person concerned in advance of the holiday, unless otherwise provided in an agreement applicable to him and the employer» [5].

Minister of Social Policy of Ukraine has given their explanation about use of the ILO Convention № 132.

Taking into account provisions of mentioned Convention and the fact, that concrete period of annual leave or its part is harmonized between an employer and employee in case of receiving it on short notice (in connection with family circumstances, health issues, etc.), employee can express his will about receiving wage in terms, determined by agreement between employer and employee [6].

This notion is rather problematic due to a number of reasons.

According to the Code of Laws about Labour of Ukraine:

If an international treaty or a contract, ratified by Ukraine, provides rules, different from national labour legislation, then rules of an international treaty or a contract must be used (paragraph $8^{1}$ ).

Conditions of labour contracts, that worsen the legal position of employees, comparing with labour legislation of Ukraine, are not valid (paragraph 9).

Salary for all the period of annual leave is paid no later than three days before the vacation starts (part 4 paragraph 115) [7].

The ILO Constitution regulates, that «in no case shall the adoption of any Convention or Recommendation by the Conference, or the ratification of any Convention by any Member, be deemed to affect any law, award, custom or agreement which ensures more favourable conditions to the workers concerned than those provided for in the Convention or Recommendation (part 8, paragraph 19) [8].»

Thus, part 4 of the paragraph 115 of the Code of Laws about Labour of Ukraine contains peremptory norm, which can't be changed by the parties of labour contract, then a labour contract, concluded by the employer and employee about other period of vacation pay, is invalid.

Chapter 19 of the Law about Labour of Republic of Latvia [9] mentions pays for work. According to the part 69, payments for work terms: ...(4) vacation pay and pays for work before leave are paid no later than one day before leave.

National legislation will take precedence over international convention due to mentioned above norm of ILO Constitution.

There are questions in practice about actual realization of the part 4, paragraph 115 of the Code of Laws about Labour of Ukraine, if an employee wishes (and employer doesn't mind) to take annual paid leave (part of the leave) against leave schedule (family issues, last-minute ticket, unplanned renovation). We consider, that in this case an employer can't be accused in non-compliance of the guarantee about vacation pay in three days before leave, if an employee's appeal is submitted 2 days before vacation. And if an employer cooperates, providing an employee with leave in period 
he asks, then vacation pay can be paid in period, different from period of the part 4, paragraph 115 of the Code of Laws about Labour of Ukraine. It is thus useful to harmonize not only the period of leave by the employer and employee but the period of vacation pay as well.

In order to avoid misunderstandings with controlling bodies, we recommend to add the paragraph 115 of the Code of Laws about Labour of Ukraine with the part 5: «In case when an employee and employer reach agreement about taking annual paid leave (part of the leave) against leave schedule and /or more quickly (less, than 14 calendar days before leave), vacation leave is paid in term, agreed between an employee and employer but no later than the next part of the wage».

\section{References:}

1. Konstytutsiia Ukrainy vid 28 chervnia 1996 r. \#254k. URL: https://zakon.rada.gov.ua/ laws/show/254\%D0\%BA/96-\%D0\%B2\%D1\%80 (accessed 19.06.2019).

2. Pro ratyfikatsiiu Konventsii Mizhnarodnoi orhanizatsii pratsi \#132 (perehlianutoi) 1970 roku pro oplachuvani vidpustky Zakon Ukrainy vid 29 travnia 2001 r. \#2481. URL: https://zakon.rada.gov.ua/laws/show/2481-14 (accessed 19.06.2019).

3. Konstytutsyia Latvyiskoi Respublyky. URL: https://www.president.lv/ru/latviiskayarespublika/konstituciya-latvii (accessed 25.06.2019).

4. Labklājības ministrija. URL: http://www.lm.gov.lv/rus/otraslevaya-politika/rabota/0-2018-1009-17-32-16 (accessed 25.06.2019).

5. Konventsiia pro oplachuvani vidpustky \#132 (perehlianuta u 1970 rotsi) vid 24 chervnia 1970 r. \#132 URL: https://zakon.rada.gov.ua/laws/show/993_022 (accessed 19.06.2019).

6. Lyst Ministerstva sotsialnoi polityky vid 05 sichnia 2012 r. \#7/13/133-12. URL: https://zakon.rada.gov.ua/rada/show/v0007739-12 (accessed 19.06.2019).

7. Kodeks zakoniv pro pratsiu Ukrainy vid 10 hrudnia 1971 r. \#322. URL: https://zakon.rada.gov.ua/laws/show/322-08\#n561 (accessed 19.06.2019).

\section{DIFFERENCES IN THE FUNDAMENTAL RIGHTS UNDERSTANDING: DOES THE PROBLEM IN THE EUROPEAN UNION EXIST?}

\section{Olena Rym $^{1}$}

DOI: https://doi.org/10.30525/978-9934-588-11-2_62

The social component in the European Union's policy is on the rise. Thus, the Lisbon Treaty clearly has it that the EU wants to have social Europe, and with this in view the following international legal tools will be used: the European Convention for the Protection of Human Rights and Fundamental Freedoms (hereinafter referred to as the Convention) and the European Social Charter. Thus, the EU shall take into account the interpretation of the fundamental social rights in the way suggested by the European Court of Human Rights (hereinafter referred to as the ECtHR).

\footnotetext{
${ }^{1}$ Ivan Franko National University of Lviv, Ukraine
} 